\title{
Boas Novas
}

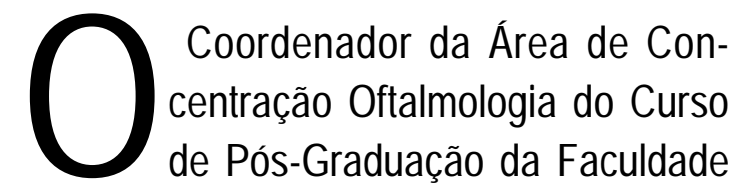
de Medicina de Ribeirão Preto, Prof.Dr. Antonio Augusto Velasco e Cruz, deu conhecimento aos docentes da Área, da qual faço parte, da divulgação feita Comitê de Consultores da CAPES - Área Medicina III - sobre os indicadores que servirão de base para avaliação continuada dos Cursos de Pós-Graduação, nessa área, no triênio 1998-2000.

O peso da produção intelectual corresponde a $30 \%$ do total, devendo ser considerado o principal item da avaliação. Diz o texto: "para sua obtenção, observar-se-ão duas categorias de produção intelectual: atividades de publicações com valor de 20 pontos (item 3) e atividades técnicas (item 5), também com valor de 20 pontos".

Desta forma, 0 item 3 diz respeito aos pontos atribuídos por número de publicações/docente/ano, com base no QUALIS- Medicina III, sendo que a pontuação correspondente a um artigo publicado em periódico QUALIS A Nacional é de 10 pontos e Internacional, de 20 pontos.

A Revista MEDICINA (Ribeirão Preto) está classificada como A no QUALIS-Medicina III, o que nos trouxe imensa satisfação.

No final do ano passado, a Comissão de Pós-Graduação e a Superintendência do Hospital das Clínicas promoveram uma reunião, em Ribeirão Preto, para discutir a avaliação da CAPES. Um dos pontos levantados foi a preocupação dos editores de periódicos nacionais com 0 escasso recebimento de artigos de boa qualidade, uma vez que os professores universitários preferiam enviar seus melhores artigos para revistas de impacto elevado, pois, só assim, esses seriam valorizados nas avaliações. E, sem um grande número de bons artigos, uma revista não consegue ter "impacto", estabelecendo-se um ciclo vicioso. Suponho que a valorização de algumas revistas nacionais no QUALIS foi um dos frutos daquela reunião.

Sem dúvida, pelo menos docentes de áreas cirúrgicas passarão a considerar nossa revista como adequada para a publicação dos artigos originais e de boa qualidade que produzirem; assim, talvez, possamos vir a ter uma revista de "impacto" internacional.

Outra boa notícia é que nossa revista, já indexada no LILACS, está sendo também indexada na EMBASE (Excerpta Medica database); acabamos, portanto, de completar o processo iniciado pelo Prof.Dr. Julio Cesar Voltarelli, ex-editor da Revista Medicina - Ribeirão Preto.

Profa.Dra. Maria de Lourdes Veronese Rodrigues Editora 